\title{
Use of a culture-independent on-farm algorithm to guide the use of selective dry-cow antibiotic therapy
}

\author{
A. K. Vasquez, ${ }^{*}$ D. V. Nydam, ${ }^{* 1}$ C. Foditsch, ${ }^{*}$ M. Wieland, ${ }^{*}$ R. Lynch, $†$ S. Eicker, $\ddagger$ and P. D. Virkler* \\ *Department of Population Medicine and Diagnostic Sciences, College of Veterinary Medicine, and \\ †Pro-Dairy, Department of Animal Science, Cornell University, Ithaca, NY 14853 \\ ¥Valley Agricultural Software, King Ferry, NY 13081
}

\section{ABSTRACT}

An algorithm using only computer-based records to guide selective dry-cow therapy was evaluated at a New York State dairy farm via a randomized field trial. DairyComp 305 (Valley Ag Software, Tulare, CA) and Dairy Herd Improvement Association test-day data were used to identify cows as low risk (cows that might not benefit from dry-cow antibiotics) or high risk (cows that will likely benefit). Low-risk cows were those that had all of the following: somatic cell count (SCC) $\leq 200,000$ cells $/ \mathrm{mL}$ at last test, an average SCC $\leq 200,000$ cells $/ \mathrm{mL}$ over the last 3 tests, no signs of clinical mastitis at dry-off, and no more than 1 clinical mastitis event in the current lactation. Low-risk cows were randomly assigned to receive intramammary antibiotics and external teat sealant (ABXTS) or external teat sealant only (TS) at dry-off. Using pre-dry-off and postcalving quarter-level culture results, low-risk quarters were assessed for microbiological cure risk and new infection risk. Groups were also assessed for differences in first-test milk yield and linear scores, individual milk weights for the first $30 \mathrm{~d}$, and culling and mastitis events before $30 \mathrm{~d}$ in milk. A total of 304 cows and 1,040 quarters in the ABXTS group and 307 cows and 1,058 quarters in the TS group were enrolled. Among cows to be dried, the proportion of cows that met lowrisk criteria was $64 \%(\mathrm{n}=611 / 953)$. Of cultures eligible for bacteriological cure analysis $(n=171), 93 \%$ of ABXTS cured, whereas $88 \%$ of TS cured. Of the noncures, $95 \%$ were contributed by the minor pathogens coagulase-negative staphylococci $(n=19 / 20)$. These organisms also accounted for $57.5 \%$ of new infections (n $=77 / 134)$. We found no statistical differences between treatment groups for new infection risk $(\mathrm{TS}=7.3 \%$ quarters experiencing new infections; $\mathrm{ABXTS}=5.5 \%$ ), milk production $(\mathrm{ABXTS}=40.5 \mathrm{~kg} ; \mathrm{TS}=41.2 \mathrm{~kg})$,

Received September 8, 2017.

Accepted November 7, 2017.

${ }^{1}$ Corresponding author: dvn2@cornell.edu linear scores $(\mathrm{ABXTS}=2.5$; $\mathrm{TS}=2.7)$, culling events (ABXTS, $\mathrm{n}=18$; TS, $\mathrm{n}=15$ ), or clinical mastitis events (ABXTS, $\mathrm{n}=9$; TS, $\mathrm{n}=5$ ). Results suggest that the algorithm used decreased dry-cow antibiotic use by approximately $60 \%$ without adversely affecting production or health outcomes.

Key words: selective dry-cow therapy, mastitis

\section{INTRODUCTION}

The rate of clinical mastitis for cows is highest within the 2 wk postcalving compared with any other time during lactation and is associated with IMI with major pathogens during the dry period (Green et al., 2002). By using serial culture throughout this period, groups have confirmed that most clinical mastitis cases are contributed by chronic subclinical or newly acquired cases from dry-off to calving (Todhunter et al., 1991; Bradley and Green, 2000; Green et al., 2002).

Dry-cow antimicrobial administration was developed and implemented in the 1960s as part of a series of management strategies to mitigate the high incidence of IMI in early lactation (Neave et al., 1966; Smith et al., 1966). A survey by the National Animal Health Monitoring System in 2014 indicated that over 90\% of cows are treated and $90 \%$ of operations use antimicrobial products at dry-off (USDA-APHIS, 2016a). This suggests that blanket dry-cow therapy (BDCT) is widely used; all quarters are treated with a longacting antimicrobial immediately after the last milking. Success of mastitis control programs is indicated by the increase in negative quarter-level culture results at dry-off from $44 \%$ in 1985 to between 73 and $95 \%$ of quarters within the last decade (du Preez and Greeff, 1985; Pantoja et al., 2009; Rajala-Schultz et al., 2011). The decreased prevalence of contagious mastitis pathogens and reduction of bulk tank somatic cell counts (BTSCC) also suggests that BDCT is not currently a necessity in all herds (Ekman and Østerås, 2003; Robert et al., 2006b). Finally, concerns exist for nonprudent use of antimicrobials in regards to public health 
consequences. For these reasons, Nordic countries have adopted restrictions that permit only selective use of antimicrobials, leading to reductions of approximately 80 and $40 \%$ for dry-cow and clinical mastitis treatments, respectively (Ekman and Østerås, 2003). External or internal teat sealants are additional technologies that can offer further protection against new IMI and are readily available in the United States (Crispie et al., 2004; Timms, 2004; Krömker et al., 2014). Selective treatment of cows at dry-off might produce economic returns via decreased labor and dry-tube costs, even when increases in incidence of mastitis are accounted for (Huijps and Hogeveen, 2007; Scherpenzeel et al., 2016).

Selective dry-cow therapy (SDCT) identifies and treats cows currently infected or at higher risk for infection during the dry period and is an alternative to BDCT. Several approaches to SDCT have been investigated, including culture-based diagnostics (Cameron et al., 2014; Patel et al., 2017). Although culture remains the gold standard for diagnosing an IMI, there are disadvantages to its use, including costs and time associated with materials, sampling, and labor. Culture-independent cow-side tools such as the California Mastitis Test and milk leukocyte differential tests are available and have been used in SDCT protocols (Poutrel and Rainard, 1981; Hockett et al., 2014). Fair to good sensitivities and specificities have been reported for diagnosing IMI from late-lactation milk samples using these tests, depending upon cut-point and interpretation (Godden et al., 2017). Use of a single composite SCC before dry-off to serve as a proxy for inflammation and infection has also been used to identify cows to be treated (Schukken et al., 1993; Scherpenzeel et al., 2014). However, identification and treatment of high-SCC cows or quarters at dry-off based upon 1 time point was shown to have negative consequences on udder health in several studies (Schukken et al., 1993; Scherpenzeel et al., 2014). Last, combination screening using SCC, mastitis history, with or without bacteriologic culture has produced beneficial effects for several outcomes, but successful implementation can be farmdependent (Rajala-Schultz et al., 2011; Cameron et al., 2014, 2015).

Our group tested a culture-independent method using only on-farm data in the form of a computer-driven algorithm to guide SDCT. Ninety-eight percent of large dairies (>500 cows) use an on-farm computer recordkeeping system, and $82.7 \%$ of cows in the United States are housed on operations that use these systems (USDA-APHIS, 2016b). Our approach was to use DHIA and DairyComp 305 (Valley Ag Software, Tulare, CA) records employed by 72.4 and $68 \%$ of large US dairies, respectively (USDA-APHIS, 2016b), to determine whether a cow was at low or high risk for having or acquiring an infection during the dry period. Our objective was to use an algorithm to identify low-risk cows and then compare outcomes (bacteriological cure, new infection risk, milk production, linear scores, mastitis cases, and culling) between those receiving IMM antibiotics and external teat sealant at dry-off and those receiving external teat sealant only.

\section{MATERIALS AND METHODS}

This randomized field trial was performed at a New York State commercial dairy milking 1,800 cows between June 2016 and March 2017. The rolling herd average milk production, BTSCC, culling rate, monthly clinical mastitis incidence, and 21-d pregnancy rate were $13,388 \mathrm{~kg}, 201,000$ cells $/ \mathrm{mL}, 36.2 \%, 2 \%$, and $20 \%$, respectively. Cows were housed in freestalls with reclaimed sand and calved in a pen bedded with straw. The trial herd milked most cows 3 times per day while late-lactation animals were milked twice per day. All cows eligible for dry-off according to guidelines defined by the dairy (pregnant $>220 \mathrm{~d}$ or pregnant $>180 \mathrm{~d}$ and producing $<11.4 \mathrm{~kg}$ of milk) were considered for inclusion. This farm used DHIA services, which included monthly SCC and milk weights, and DairyComp 305 (DC305; Valley Ag Software) for recording mastitis and culling events.

\section{Sample Size Calculation}

The primary outcome was new IMI at freshening, which has a documented prevalence of 6.4 to $25 \%$ at the quarter level (Godden et al., 2003; Pantoja et al., 2009; Arruda et al., 2013). Using a prevalence of $15 \%$, an $\alpha$ level of 0.05 , a power of $80 \%$, and the ability to detect a change in risk of $5 \%$, a sample size of 1,884 (942 quarters per group; 236 cows) would be required. After accounting for a $20 \%$ loss to follow-up, the sample size amounts to 2,261 quarters, or a total of 565 cows (approximately 300 cows per group).

\section{Algorithm Details, Treatment Allocation, and Sampling Procedures}

This study was approved by Cornell University Institutional Animal Care and Use Committee (approval \#2013-064). Each cow eligible for dry-off was classified into low- or high-risk groups based on the following algorithm: a low-risk cow was defined as having an average SCC over the last 3 tests before dry-off of $\leq 200,000$ cells $/ \mathrm{mL}$, an $\mathrm{SCC} \leq 200,000$ cells $/ \mathrm{mL}$ on the last test, and no more than 1 case of clinical mastitis in the current lactation. The expected dry period had 
to be $<100 \mathrm{~d}$ and each low-risk cow could not have been treated with antibiotics in the last $30 \mathrm{~d}$. All other cows were categorized as high risk by the algorithm. The computer-based algorithm was automated within DC305. All previous mastitis events were detected by farm personnel and all events were recorded in DC305 regardless of treatment protocol. Aside from computerbased assignment, if a cow had clinical mastitis on dry-off day or had $<3$ functional quarters, she was considered a high-risk cow. All high-risk cows received drycow intramammary (IMM) antibiotics and external teat sealant. Eligible low-risk cows were randomized to either the external teat sealant only (TS) group or the antibiotic and external teat sealant (ABXTS) group using a random number generator in Excel (Microsoft Corp., Redmond, WA). Low-risk cows were blocked within dry-off day, aiming to enroll an equivalent number of cows into each treatment group that day.

The trial farm had a designated weekly dry-off day. Procedures, including dry-tube antibiotic selection and use of external teat sealant, were not altered from the farm's normal routine. Subsequent to the afternoon milking, dry cows were held in a pen to await dry-off procedures. They were individually placed into a tilttable chute, teats were cleaned thoroughly with a dilute (1:128) chlorhexidine solution (2\%; AgriLabs, St. Louis, $\mathrm{MO}$ ), and teat ends were scrubbed with individual alcohol towelettes. Following initial forestripping of milk, single quarter-level samples were collected into a culture tube by study personnel using sterile technique and promptly placed on ice. Immediately after sample collection, cows in the ABXTS group received 1 tube of cephapirin benzathine into each quarter according to label directions (ToMorrow; Boehringer Ingelheim, St. Joseph, MO). Subsequent to administration of the drycow antibiotic, an external teat sealant (T-hexx Dry; Hydromer Inc., Branchburg, NJ) was applied once to each barrel and teat end. For cows in the TS group, only the external teat sealant was applied once to each barrel and teat end. Treatments were applied on a cow level; all quarters of cows in each group received antibiotics (ABXTS) or did not (TS). All cows were dried off abruptly and dry-cow treatments and external teat sealants were administered by farm personnel.

A red leg band was placed on every dry cow regardless of administration of antibiotics, and management did not maintain records as to which cows received treatments, although the study investigators did. Each cow was also marked as treated with antibiotics in an effort to minimize bias when milkers or management detected cases of mastitis or made culling decisions as well as to avoid residue issues. All trial cows remained in the dry-cow pens or maternity pens until milk withdrawal times were met and milk production commenced. Any mastitis case defined during the trial was detected by on-farm employees, trained by Quality Milk Production Services (QMPS), by observing abnormalities in milk, inflammation of the quarter, or systemic signs in the cow. Milk samples from all mastitis cases were submitted to QMPS at the Animal Health and Diagnostic Center (Ithaca, NY) for culture. Events (mastitis, sold, died) were recorded in DC305 by on-farm employees.

Quarter-level samples were obtained from each lowrisk cow after milking in the parlor at 1 to 7 DIM. Teat ends were scrubbed with individual alcohol towelettes, and samples were taken following an initial forestrip procedure. If a cow received antimicrobial treatment before collection of the postcalving sample, its samples were removed from the quarter-level analyses.

Quarter-level samples were also retrieved on dry-off day and at 1 to $7 \mathrm{~d}$ fresh from a subset of high-risk cows to describe organism distribution and to calculate the positive and negative predictive values of the algorithm. Positive predictive value (PPV) is the probability that a cow assigned to the high-risk group has 1 or more positive quarters. Negative predictive value (NPV) is the probability that a cow assigned to the low-risk group had 4 negative quarters on culture.

\section{Microbiological Diagnosis}

Standard culture technique was performed on all milk samples by QMPS following procedures recommended in the Laboratory Handbook on Bovine Mastitis (National Mastitis Council, 2017). Briefly, $0.01 \mathrm{~mL}$ of milk was streaked on trypticase soy agar containing $5 \%$ sheep blood and 1\% esculin (PML Microbiologicals, Mississauga, ON, Canada), and plates were incubated aerobically at $37^{\circ} \mathrm{C}$ for 18 to $24 \mathrm{~h}$. Colonies from pure cultures were subjected to matrix-assisted laser desorption/ionization time-of-flight (MALDI-TOF) using a Bruker MALDI-TOF Biotyper (version 3.1.66; Bruker Corp., Billerica, MA). Confidence levels were assigned by the machine software by referencing the Bruker 5989 RUO bacterial library. Levels accepted for species identification were $\geq 2.0$ and for genus identification between 1.8 and 2.0. A composite sample was created by combining $300 \mu \mathrm{L}$ of milk from each quarter for each cow for mycoplasma testing. Pools of milk from 5 cows were subjected for mycoplasma screening using a dissection microscope after anaerobic incubation at $37^{\circ} \mathrm{C}$ for $7 \mathrm{~d}$ on mycoplasma agar (Sigma-Aldrich LLC, St. Louis, MO).

\section{Treatment Outcomes}

Quarters were assessed for bacteriological cure and new infection risk. Only quarters with pure, noncon- 
taminated cultures were considered. Exclusions for these reasons did not differ between groups (Tables 2 and 4). For all pathogens except CNS, an infection was defined as the isolation of one or more colonies from 10 $\mu \mathrm{L}$ of milk. For CNS, 2 or more colonies isolated from the sample were needed to establish the presence of an infection (Dohoo et al., 2011). If 1 nonpathogenic or $\geq 2$ dissimilar nonpathogenic colony types were present at low levels, the culture was defined as negative. Contamination was defined as the isolation of $\geq 3$ different colony types from the milk sample. A quarter was defined as a bacteriological cure when the initial pathogen present at enrollment was not present in the fresh quarter sample. Negative quarters at dry-off were not included in analysis for bacteriological cure. A quarter was defined as a new infection when the organisms cultured at dry-off and at freshening were different. If a cow left the trial due to culling during the dry period or was missed for any reason at freshening, it was lost to follow-up for both bacteriological cure and new infection risk. Cows in the study were also followed up for first-test (1-41 d) milk production and linear scores, longitudinal milk production up to 30 DIM, mastitis events before 30 DIM, and survival/removal from the herd before 30 DIM. These values and dates were retrieved from DHIA monthly reports or DC305. Linear score $(\mathbf{L S})$ is a transformation of SCC, calculated as $[\ln (\mathrm{SCC} / 100) / \ln (2)]+3$ (Ali and Shook, 1980).

\section{Statistical Analysis}

The effects of treatment on outcomes were analyzed using generalized linear mixed models for continuous variables and binomial logistic regression for dichotomous outcomes. Analysis of outcomes accounted for important covariates such as parity at freshening (second, third, fourth, or > fourth), DIM at sample collection, length of the dry period, previous milk yield and LS, mastitis events before and after the dry period (up to 30 DIM), and pathogen present at dry-off and at freshening. The primary explanatory variable of interest was treatment group and all interactions with this variable were tested. All analyses were performed in SAS version 9.4 (SAS Institute Inc., Cary NC) using the PROC LOGISTIC command for binary outcomes: bacteriological cure, new infection risk, mastitis before 30 DIM, and culling before 30 DIM. The PROC MIXED command was used for milk production (longitudinal and at first test) and LS at first test. Each quarter was treated as an independent observation in the analysis of bacteriological cure and new infection risk. To select the best model, all possible confounding variables were subjected to bivariate analysis by means of Chi-squared, t-tests, or ANOVA tests using
PROC FREQ, PROC TTEST, PROC REG, or PROC ANOVA. Any terms with $P<0.2$ were offered into the models. Each variable was then examined by backward stepwise removal from the regression until all covariates with $P<0.1$ were identified and included. In many of the models, the treatment variable was forced. Quarter nested in cow was tested as a random effect to determine the contribution of interdependence of quarters. Basic graphing techniques were used to assess normality, homoscedasticity, and linearity of variables. Data transformations were performed and reported as necessary. Seven final models were established describing (1) the odds of bacteriological cure, (2) the odds of new infection, (3) first-test milk production, (4) longitudinal milk production, (5) first-test LS, (6) the odds of culling before 30 DIM, and (7) the odds of mastitis before 30 DIM. An animal was not included in a model if it was missing a data point for a parameter included in the model; the number of animals with complete data for each analysis is indicated in each table.

\section{RESULTS}

\section{Descriptive Statistics for Low- and High-Risk Cows and Quarters}

A total of 953 cows were dried off between June 2016 and January 2017. Cows were allocated into the highrisk group $(\mathrm{n}=321)$ by the algorithm for combinations of the following criteria: high average SCC, high lasttest SCC, an anticipated dry period $>100 \mathrm{~d}$, and $>1$ mastitis event in the current lactation. More than half of the excluded cows experienced $>1$ reason for assignment into the high-risk group $(\mathrm{n}=169)$. High last-test SCC is commonly used in SDCT protocols as a criterion for administration of an IMM antimicrobial. The addition of criteria other than last-test SCC, for which 244 cows would have been excluded, resulted in an additional 77 cows assigned to the high-risk group. The 2 most common reasons for placement into the high-risk group were high SCC at last test and high average SCC over the last 3 tests $(\mathrm{n}=268$ cows equaling $28 \%$ of cows eligible for dry-off and $83 \%$ of exclusions). Cows added at the last minute to the dry-off list (not due to dry-off by the farm's criteria but elected to dry-off by management) were not sampled and not included in the either risk group $(\mathrm{n}=21)$. Details of cow and quarter enrollment can be found in Figure 1. A total of 611 lowrisk cows and 2,386 quarters were enrolled in the study. Fifty-eight cows were three-quartered. Allocation to the low-risk group was $64 \%$. Distribution between groups was similar, with $50 \%$ of cows and quarters assigned to the TS group ( $\mathrm{n}=307 / 611 ; 1,202 / 2,386)$ and $50 \%$ assigned to the ABXTS group $(\mathrm{n}=304 / 611 ; 1,184 / 2,386)$. 
Postenrollment exclusions of low-risk cows resulted in 37 cows lost for analysis of milk production and LS due to death or culling during the trial period $(\mathrm{n}=33)$ or no recorded LS $(\mathrm{n}=4)$. The number of quarters lost to follow-up for both bacteriological cure and new infection risk analyses was 288. Quarters were lost for the following reasons: no postcalving sample was collected $(\mathrm{n}=34)$, sample was retrieved $>7$ DIM $(\mathrm{n}=2)$, death or culling during early fresh or during the dry period $(\mathrm{n}=75$ quarters, 19 cows $)$, and antimicrobial treatment before postcalving milk samples were retrieved ( $\mathrm{n}=52$ quarters). An additional 125 quarters were excluded from bacteriological cure and new infection risk analyses due to contamination or mixed culture results. No statistical differences were observed between study groups with respect to postenrollment exclusions. Cows experiencing culling or missing milk samples over the dry or early fresh period were still considered for culling and mastitis outcomes and for longitudinal milk production for as long as they remained in the herd. Overall, 1,058 TS quarters and 1,040 ABXTS quarters were considered for analysis of bacteriological cure and new infection risk. Cow inclusion numbers for analyses of culling and mastitis risk was 307 TS cows and 304 ABXTS cows. Analyses of milk production and LS included 291 TS and 283 ABXTS cows (Figure 1).

Descriptors for each treatment group are found in Table 1. The distribution of cows experiencing 1 case of clinical mastitis in the lactation of enrollment was different between groups, with cows in the TS group experiencing more cases (17 vs. 6). Mean last test-day milk production and LS were $23.6 \mathrm{~kg}$ and 2.3 , respectively. The mean and median number of DIM when the fresh quarter milk sample was retrieved was 2 and $3 \mathrm{~d}$. The mean and median number of DIM that milk production and LS data were retrieved were each 16 d. Distribution of these variables was not statistically different between treatment groups.

\section{Infection Status at Dry-Off and Freshening}

A total of 142 high-risk cows ( $\mathrm{n}=553$ quarters) were sampled to determine the ability of the algorithm to correctly classify cows as high or low risk. The cow-level IMI prevalence at dry-off for high-risk and low-risk cows was 70.7\% ( $\mathrm{n}=99 / 140)$ and 29.4\% $(\mathrm{n}=178 / 605)$, respectively. The PPV and NPV for the algorithm were $70.7 \%$ (95\% CI: $65.4-76.0$ ) and 70.6\% (95\% CI: $66.4-$ 74.7) at the observed apparent prevalence of infection $(37.2 \%)$. Including mixed culture results and excluding contaminated quarters, the quarter-level prevalence for IMI was $9.6 \%(\mathrm{n}=229 / 2,379)$ and $29.8 \%(\mathrm{n}=$ $165 / 553$ ), for low- and high-risk quarters, respectively (13.4\% overall). Distribution of dry-off culture results for low- and high-risk quarters is given in Tables 2 and 3. Randomization resulted in a similar distribution of organisms between treatment groups $(P>0.05)$. The most commonly isolated organisms for both low- and high-risk cows were CNS, contributing to 4.9 and $13.9 \%$ of overall quarters and 59.8 and $46.6 \%$ of infections, respectively. Infection proportion with Corynebacterium spp. was similar between high- and low-risk quarters, but Lactococcus spp. were more prevalent in high-risk quarters.

Following calving, $7.3 \%$ of quarters in the high-risk group were culture positive $(\mathrm{n}=36 / 495)$, whereas $8.2 \%$ of low-risk quarters were culture positive $(\mathrm{n}=$ $182 / 2,225)$. The most common positive culture result was CNS, with $4.6 \%$ of the low-risk quarters and $3.0 \%$ of the high-risk quarters infected. The infection status of quarters in low-risk groups is given in Table 4 .

\section{Treatment Effects}

Bacteriologic Cure Risk. A quarter was not eligible for bacteriological cure if the dry-off sample had no growth $(\mathrm{n}=1,927)$, the dry-off or fresh sample was contaminated $(\mathrm{n}=69)$, or if the dry-off or fresh sample had mixed growth $(\mathrm{n}=56)$. The number of quarters meeting inclusion criteria for analysis was 171 . Bacteriological cure was seen in 151 of the quarters (88.3\%): $72(83.7 \%)$ of the TS quarters and $79(92.9 \%)$ of the ABXTS quarters (Fisher's exact $P=0.09$ ). This compares with high-risk cows that experienced a cure in $94.9 \%(\mathrm{n}=112 / 118)$ of quarters. Of the non-cures, $95.0 \%$ were contributed by CNS in low-risk cows (n $=19 / 20)$ and $100 \%$ in high-risk cows $(\mathrm{n}=6)$. Mixed model logistic regression of bacteriological cure produced a model that included etiology of infection and DIM at retrieval of fresh quarter sample (Table 5). While controlling for these variables, the odds ratio for bacteriological cure between TS and ABXTS was 0.32 ; bacteriological cure was approximately 3.1 times higher for ABXTS quarters than for TS quarters $(P$ $=0.04)$. Extrapolation of least squares means (LSM) for bacteriological cure for this model indicated a cure of $93.2 \%$ of TS quarters and $97.7 \%$ of ABXTS quarters. To permit for the inclusion of etiology of IMI in a regression model, the variable was condensed so that an acceptable number of quarters within each category was established. Etiology was therefore dichotomized into "CNS" and "other." When controlling for treatment group, odds of bacteriological cure for CNS-infected quarters at dry-off were lower than the grouping of "other" organisms $(P=0.03)$.

New Infection Risk. A new infection was defined as the presence of new or different growth on the dry-off quarter sample from the fresh quarter sample. Contam- 
inated and mixed growth quarters were not included in the analysis. Chronic quarters, or growth of the same organism from both samples, were included but not defined as new infections. New infections totaled $6.4 \%$ with $57.5 \%(\mathrm{n}=77 / 134)$ of new infections described as CNS. Quarters in the TS group experienced a numerically higher number of new infections $(\mathrm{n}=77 / 1,058$; $7.3 \%)$ than the ABXTS group ( $\mathrm{n}=57 / 1,040 ; 5.5 \%)$. Chi-squared analysis indicated a $P$-value of 0.09 for this difference. A logistic regression model includes parity and dry-off quarter growth (categorized into "CNS," "other," and "no growth"; Table 6). When controlling for these variables, the odds of new infection for TS versus ABXTS was 1.29 (95\% CI: $0.9-1.85 ; P=0.17$ ). New infections in the high-risk group amounted to $6.8 \%$ (n $=31 / 456)$.

Milk Production and $\boldsymbol{L} \boldsymbol{S}$. All cows with milk yield and LS values for the first test-day after calving were included in the analysis. The mean test-day milk for all low-risk cows was $40.8 \mathrm{~kg}$. A mixed linear regression model used 574 observations $(\mathrm{TS}=290$, ABXTS $=$ 284) and included LS at first test-day, milk produc-

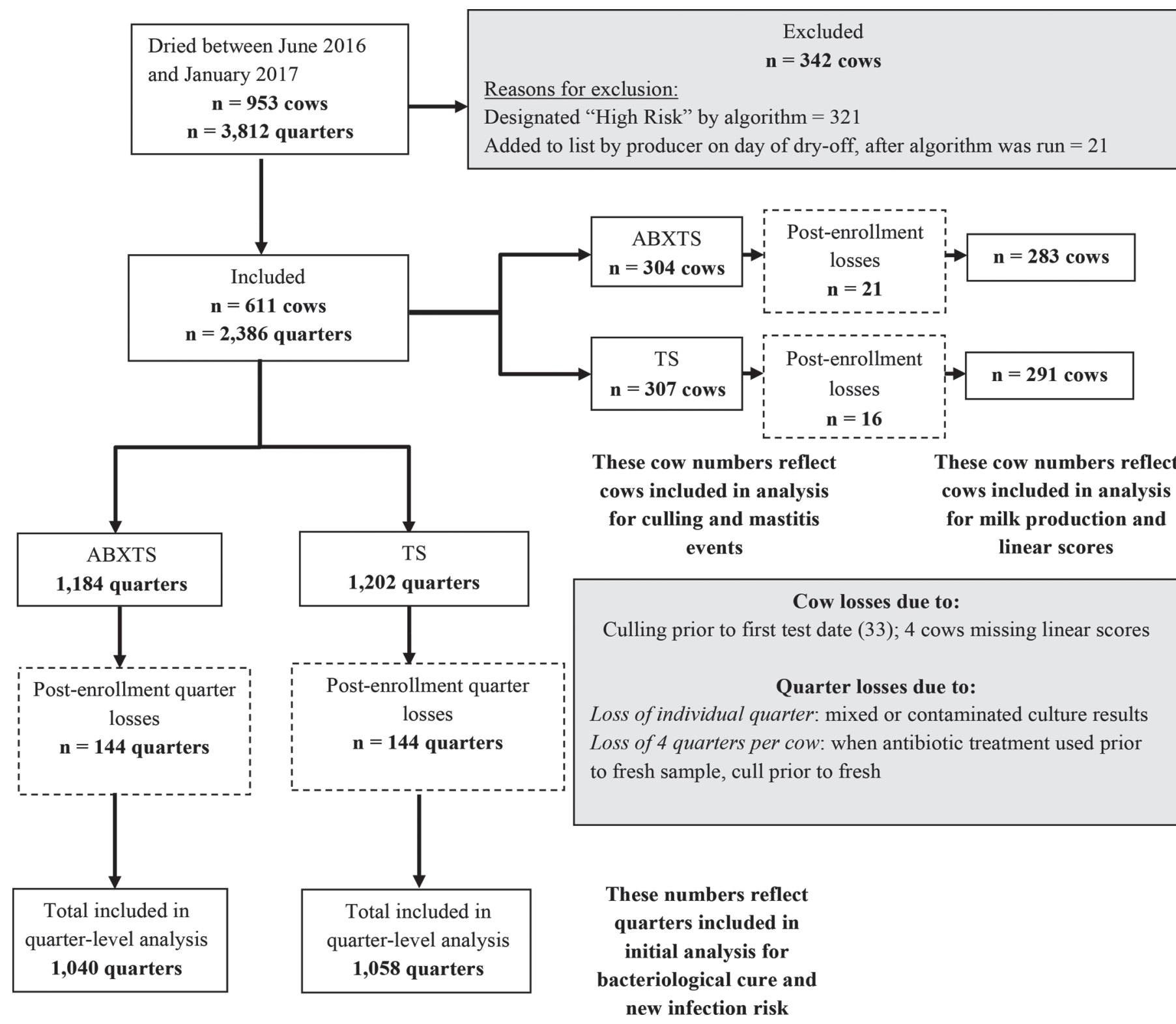

Figure 1. Enrollment of cows and quarters in a randomized field trial to evaluate the use of an algorithm that identified high- and low-risk cows to guide selective dry-cow therapy. ABXTS = low-risk cows that received antibiotic therapy and external teat sealant at dry-off; TS $=$ low-risk cows treated with external teat sealant only. 
Table 1. Descriptors for cows in a randomized field trial evaluating treatment of low-risk cows with external teat sealant (TS; $\mathrm{n}=307$ ) or antibiotics and external teat sealant (ABXTS; $\mathrm{n}=304$ ) at dry-off

\begin{tabular}{|c|c|c|c|c|}
\hline \multirow[b]{2}{*}{ Item } & \multicolumn{2}{|c|}{ Treatment group } & \multirow[b]{2}{*}{ All cows } & \multirow[b]{2}{*}{$P$-value ${ }^{1}$} \\
\hline & TS & ABXTS & & \\
\hline$\overline{\text { Parity }^{2} \text { (no.) }}$ & & & & 0.65 \\
\hline First & 136 & 140 & 276 & 0.68 \\
\hline Second & 84 & 81 & 165 & 0.86 \\
\hline Third & 52 & 42 & 94 & 0.31 \\
\hline > Third & 35 & 41 & 76 & 0.46 \\
\hline \multicolumn{5}{|l|}{$\operatorname{DIM}^{2}(\mathrm{~d})$} \\
\hline Mean & 338 & 343 & 340 & \multirow[t]{2}{*}{0.27} \\
\hline Median & 313 & 330 & 340 & \\
\hline \multicolumn{4}{|l|}{ Actual dry period (d) } & \multirow[t]{3}{*}{0.06} \\
\hline Mean & 56 & 54 & 55 & \\
\hline Median & 54 & 53 & 54 & \\
\hline \multicolumn{4}{|l|}{ Mastitis event ${ }^{3}$ (no.) } & \multirow[t]{3}{*}{0.02} \\
\hline Yes & 17 & 6 & 23 & \\
\hline No & 290 & 298 & 588 & \\
\hline \multicolumn{5}{|l|}{ Milk yield $^{4}(\mathrm{~kg})$} \\
\hline Mean & 23.6 & 23.5 & 23.6 & \multirow[t]{2}{*}{0.87} \\
\hline Median & 24.5 & 23.6 & 24.0 & \\
\hline \multicolumn{5}{|l|}{ Linear score $^{4}$} \\
\hline Mean & 2.2 & 2.3 & 2.3 & \multirow{2}{*}{0.18} \\
\hline Median & 2.2 & 2.4 & 2.3 & \\
\hline
\end{tabular}

${ }^{1} P$-values based on bivariate analysis ( $t$-test, Fisher's exact) of each variable by treatment group.

${ }^{2}$ At enrollment.

${ }^{3}$ If the cow had 1 mastitis event in the lactation before enrollment.

${ }^{4}$ At test-day before enrollment.

tion at last test-day before dry-off, and DIM on the first test-day. Treatment group was not important in the model, though numerically the TS cows produced $0.69 \mathrm{~kg}$ more milk (LSM TS $=41.2 \mathrm{~kg}$, ABXTS $=$ $40.5 \mathrm{~kg} ; P=0.35)$. As expected, as LS at first test-day increased, milk production decreased $(P<0.001)$. As milk production at last test-day or DIM at first testday increased, milk production increased $(P<0.001)$. A repeated-measures analysis performed on daily milk yields $(\mathrm{n}=15,987)$ over the first 30 DIM by treatment group is shown in Figure 2. Means for milk production were numerically greater in the TS group for each of the first 26 DIM, but neither the effect of treatment nor the treatment by time interaction was important in the model ( $P=0.20, P=0.40$, respectively). The same cows as in the milk production outcome were included in a linear regression model for first test-day LS ( $\mathrm{n}=$ 574; Table 7). The mean test-day LS for all cows was

Table 2. Quarter-level culture results at dry-off for low-risk cows randomly assigned to receive either external teat sealant (TS; $\mathrm{n}=1,204)$ or antibiotics and external teat sealant (ABXTS; $\mathrm{n}=1,183$ ) at dry-off ${ }^{1}$

\begin{tabular}{|c|c|c|c|c|c|}
\hline \multirow[b]{2}{*}{ Culture result } & \multicolumn{2}{|c|}{ TS } & \multicolumn{2}{|c|}{ ABXTS } & \multirow[b]{2}{*}{$P$-value ${ }^{2}$} \\
\hline & No. & $\%$ & No. & $\%$ & \\
\hline Negative & 1,086 & 90.2 & 1,064 & 90.0 & 0.84 \\
\hline CNS & 59 & 4.9 & 78 & 6.6 & 0.08 \\
\hline Mixed growth & 22 & 1.8 & 20 & 1.7 & 0.88 \\
\hline Corynebacterium spp. & 24 & 2.0 & 12 & 1.0 & 0.06 \\
\hline Lactococcus spp. & 5 & 0.4 & 4 & 0.3 & $>0.99$ \\
\hline Streptococcus spp. ${ }^{3}$ & 2 & 0.2 & 1 & 0.1 & $>0.99$ \\
\hline Other $^{4}$ & 6 & 0.5 & 4 & 0.3 & 0.75 \\
\hline Total IMI ${ }^{5}$ & 114 & 9.5 & 115 & 9.7 & 0.84 \\
\hline
\end{tabular}

${ }^{1}$ Etiological classification is based on aerobic culture results and matrix-assisted laser desorption/ionization time-of-flight (MALDI-TOF) performed by Quality Milk and Production Services (Ithaca, NY).

${ }^{2} P$-values based on bivariate analysis (Fisher's exact) of each etiology by treatment group.

${ }^{3}$ Includes Streptococcus dysgalactiae and Streptococcus spp. unclassified to the species level.

${ }^{4}$ Includes contamination and gram-negative and gram-positive bacilli.

${ }^{5}$ Excludes contamination. 
Table 3. Quarter-level culture results at dry-off for high-risk cows as designated by a computer algorithm in a selective dry-cow therapy $\operatorname{program}^{1}$

\begin{tabular}{lcrc}
\hline Culture result & No. $(553)$ & $\%$ & IMI $(\%)$ \\
\hline Negative & 384 & 69.4 & \\
CNS & 77 & 13.9 & 45.6 \\
Mixed growth & 27 & 4.9 & 16.0 \\
Corynebacterium spp. $_{\text {Lactococcus } \text { spp. }}^{2}$ & 14 & 2.5 & 8.3 \\
Streptococcus $^{2}$ & 35 & 6.3 & 20.7 \\
Other $^{3}$ & 8 & 1.4 & 4.7 \\
Total IMI $^{4}$ & 8 & 1.4 & 4.7 \\
\hline
\end{tabular}

${ }^{1}$ Etiological classification was based on aerobic culture results and matrix-assisted laser desorption/ionization time-of-flight (MALDI-TOF) performed by Quality Milk and Production Services (Ithaca, NY).

${ }^{2}$ Includes Streptococcus dysgalactiae and Streptococcus spp. unclassified to the species level.

${ }^{3}$ Includes contamination, Pseudomonas spp., Serratia spp., and grampositive bacilli.

${ }^{4}$ Excludes contamination.
2.6. When controlling for other independent variables included in a linear regression model, the LSM for LS was numerically higher for the TS group $(P=0.10)$. Important in the model were the type of growth on dryoff and fresh samples, parity, mastitis before 30 DIM (dichotomized into "yes" or "no"), DIM at first test, and milk production at first test. A negative culture result for all 4 quarters at dry-off or fresh sampling was associated with a lower LS than a result of "CNS" or "other" for at least 1 quarter. Cows entering their second lactation had a lower LS than any other category of parity $(P<0.05)$. A cow that experienced mastitis within the first 30 DIM had a higher linear score than one that had not $(P<0.05)$.

Culling and Mastitis Events. All cows enrolled were included in logistic regression models for culling and mastitis events up to 30 DIM. Overall, $94.6 \%$ of enrolled cows remained in the herd until they reached 30 DIM. A total of 33 cows were culled or died, 18 in the

Table 4. Quarter-level culture results at fresh for low-risk cows randomly assigned to receive either external teat sealant (TS; $\mathrm{n}=1,128$ ) or antibiotics and external teat sealant (ABXTS; $\mathrm{n}=1,097$ ) at dry-off ${ }^{1}$

\begin{tabular}{|c|c|c|c|c|c|}
\hline \multirow[b]{2}{*}{ Culture result } & \multicolumn{2}{|c|}{ TS } & \multicolumn{2}{|c|}{ ABXTS } & \multirow[b]{2}{*}{$P$-value ${ }^{2}$} \\
\hline & No. & $\%$ & No. & $\%$ & \\
\hline Negative & 983 & 87.1 & 998 & 91.0 & 0.004 \\
\hline CNS & 68 & 6.0 & 34 & 3.1 & 0.001 \\
\hline Contamination & 35 & 3.1 & 27 & 2.5 & 0.37 \\
\hline Mixed growth & 12 & 1.1 & 7 & 0.6 & 0.36 \\
\hline Lactococcus spp. & 13 & 1.2 & 7 & 0.6 & 0.26 \\
\hline Streptococcus spp. ${ }^{3}$ & 8 & 0.7 & 10 & 0.9 & 0.64 \\
\hline Corynebacterium spp. & 2 & 0.2 & 6 & 0.5 & 0.17 \\
\hline Other $^{4}$ & 7 & 0.6 & 8 & 0.7 & 0.8 \\
\hline Total IMI ${ }^{5}$ & 110 & 9.8 & 72 & 6.7 & 0.007 \\
\hline
\end{tabular}

${ }^{1}$ Etiological classification is based on aerobic culture results and matrix-assisted laser desorption/ionization time-of-flight (MALDI-TOF) performed by Quality Milk and Production Services (Ithaca, NY) on samples 1 to 7 DIM.

${ }^{2} P$-values based on bivariate analysis (Fisher's exact) of each etiology by treatment group.

${ }^{3}$ Includes Streptococcus dysgalactiae, Streptococcus uberis, and Streptococcus spp. unclassified to the species level.

${ }^{4}$ Includes gram-negative and gram-positive bacilli, Escherichia coli, Klebsiella, Trueperella pyogenes, and Enterococcus spp.

${ }^{5}$ Excludes contamination.

Table 5. Logistic regression model for the risk of bacteriological cure at freshening in quarters receiving external teat sealant only (TS; $\mathrm{n}=86$ ) or antibiotic dry-cow therapy and teat sealant (ABXTS; $\mathrm{n}=85$ )

\begin{tabular}{|c|c|c|c|c|c|}
\hline Parameter & Estimate & $\mathrm{SE}$ & $P$-value & Odds ratio & $95 \%$ CI \\
\hline Intercept & 6.25 & 1.30 & $<0.0001$ & & \\
\hline Treatment group & & & 0.04 & & \\
\hline $\mathrm{TS}$ & -1.12 & 0.55 & & 0.32 & $0.11-0.96$ \\
\hline ABXTS & Referent & & & & \\
\hline Organism cultured at dry-off & & & 0.03 & & \\
\hline CNS & -2.33 & 1.05 & & 0.10 & $0.01-0.80$ \\
\hline Other & Referent & & & & \\
\hline DIM at freshening sample & -0.52 & 0.16 & 0.002 & & \\
\hline
\end{tabular}




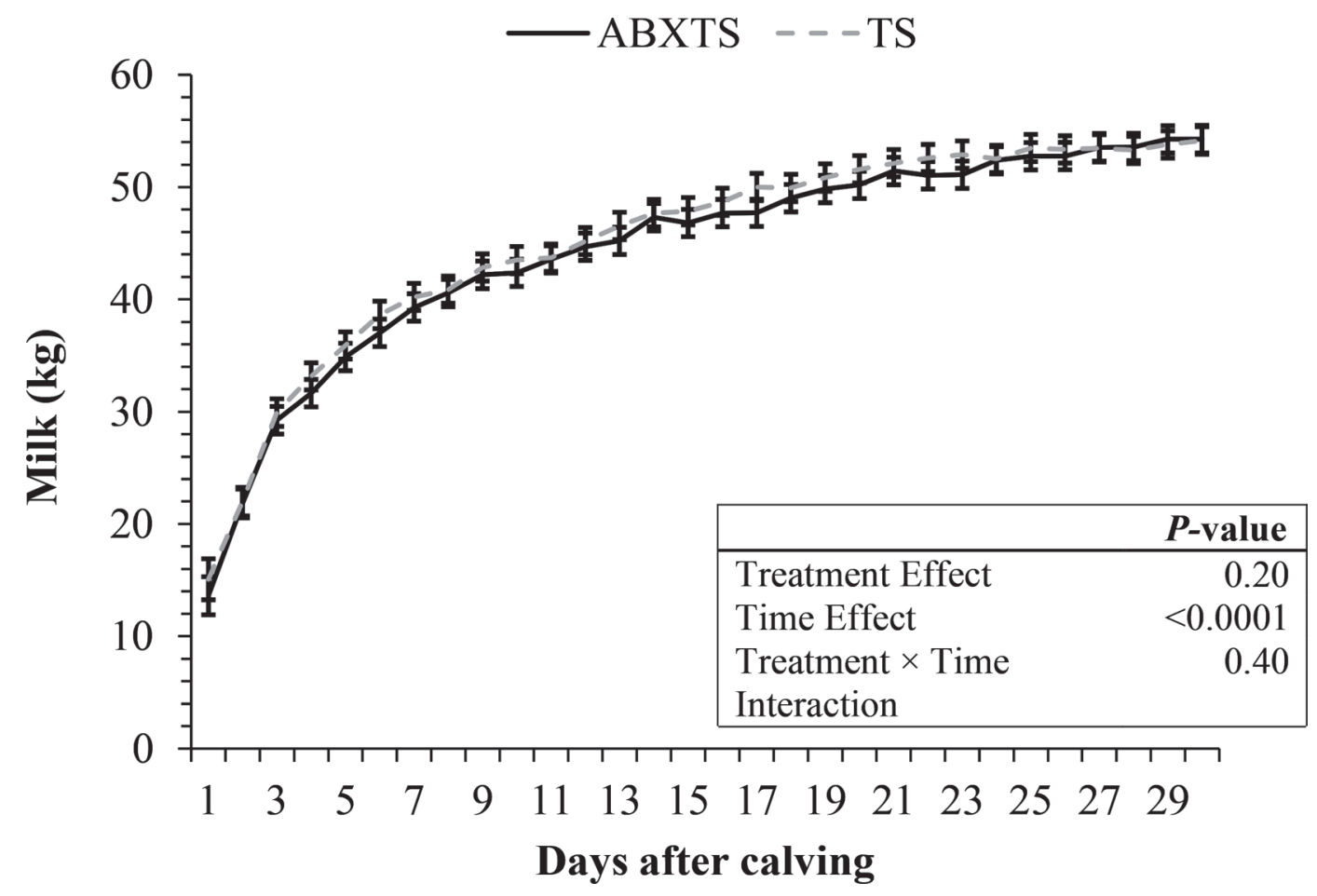

Figure 2. Longitudinal milk production $(\mathrm{kg})$ over the first 30 DIM for cows receiving external teat sealant only (TS) or antibiotic therapy and teat sealant (ABXTS) at dry-off. Error bars signify 95\% CI.

ABXTS group and 15 in the TS group (Chi-squared $P$-value $=0.57)$. In a logistic regression model, cows in the TS group had lower odds of leaving the herd than cows in the ABXTS group but we did not observe an important difference between treatment groups $(P$ $=0.60)$. The model for this outcome included parity only, with cows in parity 2 or 3 experiencing lower odds than those in parity $>4(P<0.05$; Table 8$)$. The total number of cases of clinical mastitis in the first 30 DIM was $14(2.3 \%)$, with TS cows contributing 5 cases and ABXTS contributing 9 cases $(\mathrm{Chi}$-squared $P$-value $=$
$0.27)$. Each cow $(\mathrm{n}=14)$ had a single case of mastitis. No cases of clinical mastitis were recorded during the dry period for cows in either group. Treatment group was not important in the logistic regression model, although the odds of clinical mastitis in the ABXTS group was 2.3 times higher than that in the TS group $(P=0.21$, Table 9$)$. Regression analysis included LS at first test and whether the cow had 1 mastitis event during the lactation of enrollment (yes or no). As expected, when controlling for important variables, the odds for mastitis were numerically higher for a cow that had

Table 6. Logistic regression model for the risk of new infection at freshening in quarters receiving external teat sealant only (TS; $\mathrm{n}=1,058$ ) or antibiotic dry-cow therapy and teat sealant (ABXTS; $\mathrm{n}=1,040$ )

\begin{tabular}{|c|c|c|c|c|c|}
\hline Parameter & Estimate & $\mathrm{SE}$ & $P$-value & Odds ratio & $95 \% \mathrm{CI}$ \\
\hline Intercept & -2.75 & 0.27 & $<0.0001$ & & \\
\hline $\begin{array}{l}\text { Treatment group } \\
\text { TS } \\
\text { ABXTS }\end{array}$ & 0.25 & 0.18 & 0.17 & 1.29 & $0.90-1.85$ \\
\hline Parity at freshening & & & 0.02 & & \\
\hline 2 & -0.45 & 0.29 & & $0.64^{\mathrm{a}}$ & $0.36-1.14$ \\
\hline 3 & 0.23 & 0.29 & & $1.25^{\mathrm{b}}$ & $0.71-2.23$ \\
\hline 4 & -0.20 & 0.34 & & $0.82^{\mathrm{ab}}$ & $0.42-1.60$ \\
\hline$>4$ & Referent & & & Referent $^{\mathrm{ab}}$ & \\
\hline Growth on dry-off sample & & & $<0.0001$ & & \\
\hline CNS & -0.10 & 0.40 & & $0.91^{\mathrm{a}}$ & $0.41-2.0$ \\
\hline Other & 1.70 & 0.36 & & $5.49^{\mathrm{b}}$ & $2.7-11.0$ \\
\hline No growth & Referent & & & Referent $^{\mathrm{b}}$ & \\
\hline
\end{tabular}

$\overline{\mathrm{a}, \mathrm{b}}$ Values within the same column and parameter with different superscripts are different $(P<0.05)$. 
Table 7. Linear regression model for linear score at first test (average DIM $=16 \mathrm{~d}$ ) for cows receiving external teat sealant only (TS; $\mathrm{n}=291$ ) or antibiotic therapy and teat sealant (ABXTS; $\mathrm{n}=283$ ) at dry-off

\begin{tabular}{|c|c|c|c|c|c|}
\hline Parameter & Estimate & $\mathrm{SE}$ & $P$-value & LSM & $95 \% \mathrm{CI}$ \\
\hline Intercept & 5.8 & 0.53 & $<0.0001$ & & \\
\hline Treatment group & & & 0.10 & & \\
\hline TS & 0.22 & 0.13 & & 2.7 & $2.5-2.9$ \\
\hline ABXTS & Referent & & & 2.5 & $2.3-2.6$ \\
\hline Growth on dry-off sample ${ }^{1}$ & & & 0.002 & & \\
\hline CNS & 0.36 & 0.18 & & $2.8^{\mathrm{b}}$ & $2.5-3.1$ \\
\hline Other & 0.65 & 0.19 & & $3.1^{\mathrm{b}}$ & $2.7-3.4$ \\
\hline No growth & Referent & & & $2.4^{\mathrm{a}}$ & $2.3-2.6$ \\
\hline Growth on fresh sample $^{1}$ & & & $<0.0001$ & & \\
\hline CNS & 1.30 & 0.21 & & $3.6^{\mathrm{b}}$ & $3.2-4.0$ \\
\hline Other & 0.72 & 0.18 & & $3.0^{\mathrm{b}}$ & $2.7-3.3$ \\
\hline No growth & Referent & & & $2.3^{\mathrm{a}}$ & $2.2-2.5$ \\
\hline Parity at freshening & & & $<0.0001$ & & \\
\hline 2 & -0.67 & 0.22 & & $2.2^{\mathrm{a}}$ & $2.1-2.4$ \\
\hline 3 & -0.18 & 0.23 & & $2.7^{\mathrm{b}}$ & $2.5-3.0$ \\
\hline 4 & 0.09 & 0.26 & & $3.0^{\mathrm{b}}$ & $2.7-3.3$ \\
\hline$>4$ & Referent & & & $2.9^{\mathrm{b}}$ & $2.5-3.3$ \\
\hline Mastitis before 30 DIM & & & 0.0006 & & \\
\hline No & -0.18 & 0.15 & & $2.5^{\mathrm{a}}$ & $2.4-2.7$ \\
\hline Yes & Referent & & & $4.2^{\mathrm{b}}$ & $3.2-5.1$ \\
\hline DIM at first test & -0.03 & 0.01 & 0.008 & & \\
\hline Milk $(\mathrm{kg})$ at first test & -0.03 & 0.007 & $<0.0001$ & & \\
\hline
\end{tabular}

${ }^{\mathrm{a}, \mathrm{b}}$ Values within the same column and parameter with different superscripts are different $(P<0.05)$.

${ }^{1} \mathrm{~A}$ cow had to have no growth on culture of all 4 quarters to be characterized as "No growth"; if one or more quarters contained CNS but no additional organism, she was characterized as "CNS"; any other growth was "Other."

Table 8. Logistic regression model for the risk of culling before 30 DIM for cows receiving external teat sealant only (TS; $\mathrm{n}=307$ ) or antibiotic dry-cow therapy and teat sealant (ABXTS; $\mathrm{n}=304$ )

\begin{tabular}{|c|c|c|c|c|c|}
\hline Parameter & Estimate & $\mathrm{SE}$ & $P$-value & Odds ratio & $95 \% \mathrm{CI}$ \\
\hline Intercept & -2.73 & 0.18 & $<0.0001$ & & \\
\hline Treatment group & & & 0.60 & & \\
\hline TS & -0.09 & 0.18 & & 0.83 & $0.40-1.69$ \\
\hline ABXTS & Referent & & & & \\
\hline Parity at freshening & & & 0.002 & & \\
\hline 2 & -0.78 & 0.31 & & $0.18^{\mathrm{a}}$ & $0.07-0.46$ \\
\hline 3 & -0.38 & 0.33 & & $0.26^{\mathrm{a}}$ & $0.10-0.71$ \\
\hline 4 & 0.22 & 0.33 & & $0.48^{\mathrm{ab}}$ & $0.18-1.32$ \\
\hline$>4$ & Referent & & & Referent $^{\mathrm{b}}$ & \\
\hline
\end{tabular}

${ }^{\mathrm{a}, \mathrm{b}}$ Values within the same column and parameter with different superscripts are different $(P<0.05)$.

Table 9. Logistic regression model for the risk of clinical mastitis before 30 DIM for cows receiving external teat sealant only $($ TS; $n=291$ ) or antibiotic dry-cow therapy and teat sealant (ABXTS; $\mathrm{n}=283$ )

\begin{tabular}{lcccc}
\hline Parameter & Estimate & $\mathrm{SE}$ & $P$-value & Odds ratio \\
\hline Intercept & -4.63 & 0.74 & $<0.0001$ & \\
Treatment group & -0.42 & 0.33 & 0.21 & 0.44 \\
$\quad$ TS & Referent & & 0.08 & $0.12-1.60$ \\
$\quad$ ABXTS & 0.80 & 0.45 & & $0.95-29.4$ \\
Mastitis event in lactation before enrollment & Referent & 0.13 & 0.003 & \\
$\quad$ Yes & 0.39 & 0.95 & \\
No & & & \\
\hline
\end{tabular}


experienced 1 case of mastitis during the lactation of enrollment than for a cow that had not $(P=0.08)$. Finally, as first test-day LS increased, the odds of clinical mastitis increased $(P=0.003)$.

\section{DISCUSSION}

In this study, removal of an antibiotic dry-cow treatment in cows determined to be low risk by a computerbased algorithm did not have adverse effects on new infection risk, milk yield, first-test LS, clinical mastitis, or culling compared with low-risk cows that were treated. Bacteriological cure was statistically different between the groups, with antibiotic-treated quarters at higher odds for cure. Coagulase-negative staphylococci comprised $95 \%$ of the non-cures on the trial dairy, yet these minor pathogens contributed only 1 case of clinical mastitis in low-risk cows over the trial period. Using the already incurred costs of computer and testing programs implemented on-farm, a culture-independent algorithm that selectively distinguishes between highand low-risk cows could result in a reduction in dry-cow antibiotic use of approximately $60 \%$ when low-risk cows are not treated.

It is difficult to describe the representativeness of one or more dairies by referencing an expected prevalence of dry period infection; much variation exists for new and current IMI, at both the cow and quarter levels. In the current study, the prevalence for quarter level dry-off IMI was 29.8 and $9.6 \%$ for high- and low- risk quarters, respectively, which is lower than an average quarter-level prevalence $(34.7 \%)$ in a Wisconsin study surveying 4 dairies (Johnson et al., 2016). However, 2 studies described a range of subclinical infection between 13 and $35 \%$ when collectively assessing 7 dairies in 4 states (Pantoja et al., 2009; Arruda et al., 2013). One common finding is that most infections are characterized as CNS: in the current trial, $60 \%$ of IMI in low-risk quarters at dry-off were CNS. This is similar to the $69 \%$ documented in the study by Johnson et al. (2016).

Despite a greater number of CNS-positive quarters allocated to the ABXTS group, creating potential bias against these quarters, the odds for bacteriological cure was greater for this group. Our higher odds of cure for antibiotic-treated quarters versus untreated quarters agreed with the conclusions of a meta-analysis of 4 SDCT trials and 13 BDCT trials, although our odds ratio of 3.1 was greater than the meta-analytic pooled relative risks of 1.76 and 1.78 , respectively (Halasa et al., 2009b). A recent trial by Cameron et al. (2014) found no statistical difference in bacteriological cure between BDCT quarters and SDCT quarters from 16 Canadian herds when treatment was performed at the cow level
( $\mathrm{n}=729$ cows). A similar study on a dairy in Minnesota ( $\mathrm{n}=56$ cows) implemented assignment on the cow level and treatment on the quarter level. Statistical differences were not found between BDCT and SDCT cows, although a cure risk difference of $5.7 \%$ was stated (Patel et al., 2017). This is comparable to our statistical cure risk difference of $4.5 \%$ with a larger sample size. Culture screening was performed on all SDCT cows in the Cameron et al. $(2014,2015)$ and Patel et al. (2017) trials before treatment of positive cows/quarters; the study design dictated that comparisons be made between blanket-treated cows and a group comprised of treated and untreated cows/quarters. This is one reason why differences in this outcome were observed in the current trial, in which we made comparisons between treated and untreated low-risk quarters. We did not analyze differences between treated high-risk quarters and treated low-risk quarters, nor did we include a group of untreated high-risk quarters. We structured the algorithm to determine, independently of culture and based on thresholds, which animals would likely benefit from antibiotic treatment. As high-risk quarters were projected to have a higher prevalence of pathogens, and given that commercial dry-cow preparations must meet label and efficacy requirements for Food and Drug Administration approval, IMM antimicrobials were assumed likely to be beneficial and not withheld from these animals. However, we are unable to conclude whether antibiotic therapy was appropriate in these cows.

In the current trial, the majority of quarters included in analysis for bacteriological cure (171 quarters) were contributed by the minor pathogens CNS $(\mathrm{n}=126)$ and Corynebacterium spp. $(\mathrm{n}=31)$ with 77 and $91 \%$ of nontreated and treated CNS cases curing, respectively. Similarly, the meta-analysis by Halasa et al. (2009b) found that although antimicrobial dry-cow therapy led to a $77 \%$ cure risk for CNS, spontaneous cure averaged $44 \%$, suggesting that antimicrobial therapy is effective against these organisms. In a survey performed in Belgian herds of CNS present at parturition, $20 \%$ of all quarters of multiparous cows had IMI characterized by 8 different CNS species, and over 20 different species have been found in bovine milk (Vanderhaeghen et al., 2015; De Visscher et al., 2016). When analyzed as 3 different groupings of 8 different species, those quarters treated with antimicrobials at dry-off experienced statistically lower odds of having an IMI characterized by CNS at calving relative to those that were not treated (De Visscher et al., 2016). However, there might be an advantage to the presence of CNS in quarters: some groups have observed higher milk production in CNSinfected animals relative to uninfected animals (Schukken et al., 2009; Piepers et al., 2013), and other groups, 
as reflected in a meta-analysis, see a protective effect of CNS against major pathogens in challenge studies (Reyher et al., 2012). Conversely, Berry and Hillerton (2002) found, when assessing 499 quarters, that untreated quarters with CNS infections had a 4.2 to 4.7 times greater risk of new infections with Streptococcus uberis or coliforms at calving compared with uninfected, untreated quarters. Characterization of the effects of individual CNS species requires further investigation. As no important differences in LS, milk production, risk of removal, or clinical mastitis cases caused by CNS were found between groups in the current study, we do not believe that effects of these pathogens on bacteriological cure or new infection risk are cause for concern on this particular dairy.

New IMI during the dry period is also variable and has been documented to range from 6.4 to $25 \%$ at the quarter level (Godden et al., 2003; Pantoja et al., 2009; Arruda et al., 2013). Intramammary infections present at calving have important economic consequences that result from declines in milk quantity and quality and increases in cases of clinical mastitis (Bradley and Green, 2000; Archer et al., 2014). Accordingly, dairies attempt to minimize these consequences with the use of dry-cow products. Although antimicrobial products might result in reductions in new IMI, the ranges provided were described for herds on which BDCT was performed; total elimination of IMI is difficult to achieve. Variation in the prevalence of IMI at calving between herds demonstrates that infection status is influenced by many factors, including cow (e.g., parity, SCC), management (e.g., frequency of cleaning bedding), and farm characteristics (e.g., facilities, pathogens present on the farm; Green et al., 2007, 2008). Alterations of these factors, when appropriate, could reduce IMI. With use of SDCT, we found the proportions (LSM) of untreated low-risk quarters acquiring new IMI over the dry period to be $11.2 \%$. This compares with the treated low-risk quarters at $8.9 \%$. These values were similar to the weighted mean incidences calculated by Robert et al. (2006b) of 9.9 and $6.5 \%$ for untreated and treated quarters, respectively, when considering new IMI in 13 studies that compared SDCT with BDCT. When a model was generated for risk of new IMI in the current study, we were unable to find a statistical difference between the treatment groups. No statistical differences were found for new IMI when culture diagnostics were used for targeting treatment at the cow or quarter level in a recent trial and a pilot study (Cameron et al., 2014; Patel et al., 2017). Our odds ratio of 0.77 was similar to the pooled relative risks of 0.58 and 0.55 described in 2 meta-analyses that compared BDCT with SDCT (Robert et al., 2006b; Halasa et al., 2009a). The meta-analysis performed by Halasa et al. (2009a) noted that although significant differences in relative risk were seen for protection against new quarter IMI, no statistical differences were found when the selection unit was the cow. When the Robert et al. (2006b) meta-analysis considered comparisons between a nontreated group and a BDCT group, differences in new IMI between groups were significant in 15 of 25 studies; however, pooled differences were statistically significant for streptococcal and Staphylococcus aureus IMI but not for IMI caused by CNS or coliforms. Significant findings in the majority of the studies could be due to the fact that contributions of streptococcal species and Staphylococcus aureus represented more than $35 \%$ of IMI in 50\% of the studies included. One trial included in the meta-analysis, Berry and Hillerton (2002), found that even though the overall new IMI risk was significantly higher in the untreated versus treated cows, the most frequently cultured organism contributing to new IMI in low SCC herds was Streptococcus uberis; no significant differences were found in the prevalence of CNS postcalving between treated and untreated groups. In contrast, on our trial dairy, less than $2 \%$ of infections were caused by Streptococcus spp., with most new infections $(57.5 \%)$ described as CNS. A small percentage of infections were diagnosed as Corynebacterium spp. These 2 groups of minor pathogens are known to infect quarters at the end of the dry period and, in the current trial, we speculate that we did not observe larger differences in IMI postpartum between the treatment groups because the preventive action of the dry-cow antimicrobial is no longer effective (Oliver and Jayarao, 1997; Bradley et al., 2003).

Internal teat sealant was not used in the current trial; use of an external teat sealant, rather, was a part of the existing protocol. Several studies show a benefit to the use of internal teat sealant-fewer infections and lower SCC in the subsequent lactation-whether used alone or in combination with antimicrobials (Godden et al., 2003; Rabiee and Lean, 2013). When introduced into healthy quarters, an inert, internal teat sealant without antibacterial properties is not risk-free; a case report indicates that improper administration could lead to outbreaks of mastitis pathogens (Milnes and Platter, 2003). Although the efficacy of a one-time application of external teat sealant over the course of the dry period has been questioned, studies show that some are effective at preventing new IMI during the dry period when applied regularly or according to label (Hayton, 2003; Timms, 2004; McDougall et al., 2008). Although no differences were detected between groups for the new IMI outcome in the current trial, numerical reductions in new IMI in the TS group could have occurred with use of an internal teat sealant versus an external teat sealant. Further research needs to be performed to 
determine how our algorithm performs with use of an internal teat sealant.

Cow-level outcomes such as the amount and quality of milk produced as well as clinical mastitis and culling risks, are, to a greater degree, economic outcomes, as they are more visible to the producer than bacteriological cure and new IMI risk. When linear regression models were used to analyze first-test date milk production or longitudinal production over the first 30 DIM, no important differences were found between treatment groups. This agrees with findings from 2 studies that followed selectively treated cows for greater than 180 DIM (Rajala-Schultz et al., 2011; Cameron et al., 2015). Additionally, the referenced studies found no statistical differences in SCC or log-transformation of SCC between the treatment groups, similar to the LS comparisons in current trial. These results differ from findings by Rajala-Schultz et al. (2011) and Scherpenzeel et al. (2014), who found that either next-lactational SCC or SCC at calving and 14 DIM, respectively, was significantly lower than that of untreated cows. Dissimilarities between findings could be due to the presence of higher levels of major pathogens on the included dairies, the lack of teat sealant use, or the inclusion of herds with BTSCC $>250,000$ cells $/ \mathrm{mL}$.

In the current trial, no important differences were found between treatment groups when assessing the risk of clinical mastitis during the trial period. Cameron et al. (2014) used culture as a screening tool in addition to individual SCC and found no statistical differences in clinical mastitis cases in the first 120 DIM between the selective and blanket treatment groups. In the current trial, the number of cows enrolled with a single mastitis event was not evenly distributed between the groups; more cows that had experienced a case of mastitis were allocated to the TS group. Despite enrollment distributions, a higher number of next-lactation mastitis cases were described in the ABXTS group. The number of clinical cases within 30DIM described for enrolled animals corresponded with the monthly incidence rate at this dairy. The fact that only low-risk cows were represented in this figure might explain why this number was not as high as expected for fresh animals. Accordingly, the first studies on decreased use of dry-cow therapy in herds with low BTSCC were not selective, treatment was omitted for all cows, and cows were not separated based on risk or infection status. This often resulted in an increased incidence rate of clinical mastitis. For example, when no screening process was used in a low BTSCC herd $(140,000$ cells $/ \mathrm{mL} ; \mathrm{n}=50$ cows $)$ to treat 2 and leave 2 quarters untreated within the same cow, there was a 10-fold increased risk of clinical mastitis in the untreated quarters (Schukken et al., 1993). Similarly but more recently, Scherpenzeel et al.
(2014) used a split-udder design on 1,657 cows with individual low SCC $(<150,000$ cells $/ \mathrm{mL}$ for primiparous and $<250,000$ cells $/ \mathrm{mL}$ for multiparous) and found that the incidence of clinical mastitis was 1.7 times higher in quarters dried without antimicrobials. Finally, our findings also differed from Berry and Hillerton (2002), in which untreated quarters at dry-off had significantly more cases of clinical mastitis over the dry period. In those quarters with IMI at freshening, the incidence of a subsequent case of clinical mastitis was significantly greater for untreated cows. Although all herds included in the Berry and Hillerton (2002) trial had a BTSCC of 150,000 cells $/ \mathrm{mL}$, only cows with no IMI, CNS, or Corynebacterium spp. 1 wk before dry-off could be randomized into treatment groups. Therefore, cows at risk due to historically higher SCC or multiple mastitis events were among the cows included in the nontreated group. Inclusion of more variables in our algorithm allowed us to capture cows with these characteristics. Berry and Hillerton (2002) also noted discrepancies in detection rates between farms and between pathogen types, and noted that 1 farm contributed to a large portion $(>70 \%)$ of the clinical cases. Employees responsible for mastitis detection in the current trial were blinded to treatment and therefore could not be biased when detecting cases of clinical mastitis.

The few cases of clinical mastitis experienced over the trial period $(\mathrm{n}=14)$ could explain why mastitis was not important in a model that evaluated culling. Culling was not statistically different between treatment groups. A limited number of SDCT trials evaluate or describe survival or culling risks between treatment groups. Østerås and Sandvik (1996) found a numerically shorter lifespan (30 d shorter) for cows in placebo-treated and untreated groups versus those cows receiving antibiotics in infected quarters when using Cox modeling over an entire lactation. However, Cox and logistic regression analysis did not produce a significant association with the dry-cow therapy regimen in that study.

To our knowledge, this is the first clinical trial that used a computer-automated system that relied on DHIA test-day data and recorded mastitis events to determine dry-cow antibiotic treatment. Using bacteriological culture is the current gold standard to diagnose an IMI. Accordingly, the accuracy measurements of the algorithm to identify IMI in this study are based on comparisons to this diagnostic tool. Nearly all $(>90 \%)$ of the low-risk quarters were uninfected at dry-off, indicating that the method of using sequential test-day SCC (as an average of the last 3 ) in addition to the use of last test-day SCC and mastitis events was good for identifying cows that had mostly uninfected quarters on the trial dairy. At the apparent prevalence of IMI at 
the current dairy, the PPV and NPV of the algorithm were approximately $70 \%$. These values indicate, based on initial quarter-level culture results, the probability that a cow identified as low risk was experiencing an IMI and was not treated with antibiotics was $30 \%$ (1 - NPV); and the probability that a cow identified as high risk was not experiencing an IMI and was treated was $30 \%$ ( 1 - PPV). High prevalence of minor pathogens might explain suboptimal predictive values. When only cows with major pathogens were characterized as infected, the NPV and PPV became 92 and 38\%, again suggesting that a large proportion of cows designated by the algorithm as high risk were not infected but were treated. More importantly, cows allocated by the algorithm to the low-risk group infrequently cultured with major pathogens. It is important to recognize that the algorithm was used to capture and treat not only cows with current infections (culture positive) but also those cows at risk for acquiring infections throughout the dry period, a characteristic that would be difficult to predict or include in these calculations. The PPV was higher than the $42.5 \%$ found in an SDCT trial that used an SCC threshold of 200,000 cells $/ \mathrm{mL}$ for 3 consecutive months before dry-off and no cases of mastitis to determine which cows to treat (Torres et al., 2008). Reasons for dissimilarities in predictive values could be due to the addition of criteria in the current algorithm or differences in IMI prevalence on the test dairies. For an increase in apparent prevalence of $5 \%$, the PPV and NPV of the algorithm would be 74.5 and $66.2 \%$; for a decrease of $5 \%, \mathrm{PPV}$ and NPV would be 65.8 and $75.1 \%$. The predictive values of our algorithm are affected by study design. Treatment assignment was on the cow level, whereas bacteriological sampling was on the quarter level. A discrepant quarter-level result within 1 cow could greatly affect the predictive value calculation. As an example, if a cow was defined as low risk by the algorithm but had 1 bacteriologically positive quarter and 3 negative quarters, the overall NPV of the algorithm would decrease. Regardless, we elected to apply treatment at the cow level as other groups have shown an interdependence of quarters toward new infection during the dry period, particularly in herds with higher risk of infection (Browning et al., 1994; Robert et al., 2006a). Additionally, $72 \%$ of large US dairies use DHIA for milk recording data, and although the most accurate relationship exists between quarterlevel SCC and IMI, producers only have access to cow composite information (Schukken et al., 2003; USDAAPHIS, 2016a).

We used a threshold of 200,000 cells/mL as a component of our algorithm. Other groups have shown that this is the optimal level to decrease error related to detection of IMI, with the highest sensitivities and speci- ficities amounting to, at best, 0.75 and 0.90 (Dohoo and Leslie, 1991; Schepers et al., 1997). However, the sensitivity and specificity of using only last-test SCC as an indicator of IMI at a threshold of 200,000 cells/mL is approximately 0.4 and 0.8 (Pantoja et al., 2009). This likely is due to the slight increases in SCC experienced by a late-lactation cow as she approaches dry-off and is a reason why decisions should not be based exclusively on a late-lactation SCC (Schepers et al., 1997; Bradley and Green, 2004). In contrast, Green et al. (2007) found that at least $1 \mathrm{SCC} \geq 200,000$ cells/mL within the last $90 \mathrm{~d}$ before drying off was associated with an increased rate of clinical mastitis in the periparturient period. The most efficient use of thresholds in an SDCT protocol was identifying cows using 3-mo SCC records with a threshold of 200,000 cells/mL for cows without clinical mastitis during the lactation and a threshold of 100,000 cells $/ \mathrm{mL}$ during the rest of the lactation for cows with clinical mastitis during the first 90 DIM (Torres et al., 2008). These findings support the need to interpret SCC as well as other health data (e.g., mastitis events) when making treatment decisions.

Treatment decisions are also influenced by economics. A benefit of the algorithm used in this trial is the adaptability of the parameters used to define a lowrisk cow. The SCC thresholds can be manipulated to increase sensitivity and decrease risk. Because no important differences were seen in milk production, LS, clinical mastitis cases, or culling, savings in labor and antimicrobial costs would result with use of SCC thresholds lower than those tested. Few SDCT studies provide economic analysis, and the directionality of the effect is dependent upon accuracy, labor, and costs of the test method; cost of the antibiotic; and the prevalence of IMI at dry-off in the herd. Use of quarter-level culture results to drive selective treatment on a farm with a dry-off IMI prevalence of $34.8 \%$ resulted in a savings of $\$ 2.77$ per cow using fixed costs for materials, labor, and IMM antibiotics (Patel et al., 2017). When a threshold composite SCC was used in an SDCT protocol to model economic returns, only 2 out of 8 scenarios resulted in gains: use of a 50,000 cells $/ \mathrm{mL}$ cutoff for both heifers and cows or use of a 150,000 cells/ $\mathrm{mL}$ for heifers and a 50,000 cells/mL cutoff for cows (Scherpenzeel et al., 2016). The 6 alternate strategies resulted in economic losses over benefits due to differences observed in the incidence rates of clinical mastitis and subclinical mastitis between the treated and untreated animals. Another economic model was built to calculate farm-specific costs of mastitis related to the dry period using trial data and expert interviews. In it, SDCT was economically the best option compared with BDCT or no antimicrobial use (Huijps and Hogeveen, 2007). However, the optimal decision was dependent 
upon the herd-specific rate of infection and other farm traits such as the attitude of the farmer toward risk. Of note, if regulations are placed on antimicrobial drytube use for US dairies, economics might play less of a role on the selection of an SDCT protocol.

One weakness of the current trial is the inclusion of a single dairy rather than a probabilistic sample of all eligible dairies. Using a power of $80 \%$ and a Type I error risk of 0.05 , a sensitivity analysis for each regression model indicated that we were able to detect odds ratios of 0.3 or lower and 1.3 or greater for bacteriological cure and new infection risks, respectively; odds ratios of 0.3 or lower for both clinical mastitis and culling risks; a difference in LS of 0.4 or greater; and a difference in longitudinal milk production of $1 \mathrm{~kg}$ when comparing TS and ABXTS. This herd represented dairy farms in the region that might wish to use a SDCT program with respect to production, BTSCC, facilities, and herd size. As indicated from the large ranges of prevalence of quarter-level infection status at dry-off and postpartum, there is much variability between dairies. This variability could result in detectable differences in the outcomes investigated, but smaller, significant differences might not always be important. This is corroborated in the study by Rajala-Schultz et al. (2011) in which an SCC difference as small as 20,000 cells/ $\mathrm{mL}$ was found to be significant when 4 dairies were included in a trial. Likewise, results could be largely influenced by 1 herd and the effects of SDCT can be opposite across herds (beneficial in some and detrimental in others). This dictates the need for farm-specific decisions when developing dry-cow protocols. Overall, the willingness of producers to adopt a selective treatment strategy at dry-off relies on an accurate, easily accessible, and cost-effective method to identify cows, reserving antimicrobial treatment for cows that will benefit most.

\section{CONCLUSIONS}

Use of selective dry-cow therapy protocols, such as the algorithm identified in this trial, protects aspects of public health by reducing the risk of bulk tank antimicrobial residues and minimizing the potential for antimicrobial resistance. Similar protocols at appropriate dairies can reduce dry-cow antimicrobial use by approximately $60 \%$ without negative consequences on new infection risk or cow-level production and health outcomes. More research is needed to determine the characteristics of farms that lead to successful implementation of SDCT algorithms; however, utilizing only on-farm data would obviate the need for microbiologic or cow-side methods that require labor, time, and money.

\section{ACKNOWLEDGMENTS}

This study was financially supported by the Engaged Cornell Graduate Student Scholarship and a grant from the New York State Farm Viability Initiative. The authors appreciate the contributions and cooperation of the dairy producer and farm employees. We acknowledge the support of QMPS (Ithaca, NY) technicians and sampling help from the following colleagues and students at Cornell University: Valeria Alanis, Germán Granados, Anne Hesse, Wolfgang Heuwieser, Rachel Murphy, Anja Sipka, Tiago Tomazi, and Monique Obsharski.

\section{REFERENCES}

Ali, A. K. A., and G. E. Shook. 1980. An optimum transformation for somatic cell concentration in milk. J. Dairy Sci. 63:487-490. https://doi.org/10.3168/jds.S0022-0302(80)82959-6.

Archer, S. C., F. Mc Coy, W. Wapenaar, and M. J. Green. 2014. Association between somatic cell count during the first lactation and the cumulative milk yield of cows in Irish dairy herds. J. Dairy Sci. 97:2135-2144. https://doi.org/10.3168/jds.2013-7158.

Arruda, A. G., S. Godden, P. Rapnicki, P. Gorden, L. Timms, S. S. Aly, T. W. Lehenbauer, and J. Champagne. 2013. Randomized noninferiority clinical trial evaluating 3 commercial dry cow mastitis preparations: I. Quarter-level outcomes. J. Dairy Sci. 96:4419 4435. https://doi.org/10.3168/jds.2012-6461.

Berry, E. A., and J. E. Hillerton. 2002. The effect of selective dry cow treatment on new intramammary infections. J. Dairy Sci. 85:112 121. https://doi.org/10.3168/jds.S0022-0302(02)74059-9.

Bradley, A. J., J. Huxley, and M. Green. 2003. A rational approach to dry cow therapy. In Pract. 25:12-17. https://doi.org/10.1136/ inpract.25.1.12.

Bradley, A. J., and M. J. Green. 2000. A study of the incidence and significance of intramammary Enterobacterial infections acquired during the dry period. J. Dairy Sci. 83:1957-1965. https://doi.org/ 10.3168/jds.S0022-0302(00)75072-7.

Bradley, A. J., and M. J. Green. 2004. The importance of the nonlactating period in the epidemiology of intramammary infection and strategies for prevention. Vet. Clin. North Am. Food Anim. Pract. 20:547-568. https://doi.org/10.1016/j.cvfa.2004.06.010.

Browning, J. W., G. A. Mein, P. Brightling, T. J. Nicholls, and M. Barton. 1994. Strategies for mastitis control: Dry cow therapy and culling. Aust. Vet. J. 71:179-181. https://doi.org/10.1111/j.1751 -0813.1994.tb03383.x.

Cameron, M., G. P. Keefe, J. P. Roy, H. Stryhn, I. R. Dohoo, and S. L. McKenna. 2015. Evaluation of selective dry cow treatment following on-farm culture: Milk yield and somatic cell count in the subsequent lactation. J. Dairy Sci. 98:2427-2436. https://doi.org/ $10.3168 /$ jds.2014-8876.

Cameron, M., S. L. McKenna, K. A. MacDonald, I. R. Dohoo, J. P. Roy, and G. P. Keefe. 2014. Evaluation of selective dry cow treatment following on-farm culture: Risk of postcalving intramammary infection and clinical mastitis in the subsequent lactation. J. Dairy Sci. 97:270-284. https://doi.org/10.3168/jds.2013-7060.

Crispie, F., J. Flynn, R. P. Ross, C. Hill, and W. J. Meaney. 2004. Dry cow therapy with a non-antibiotic intramammary teat seal-A review. Ir. Vet. J. 57:412-418. https://doi.org/10.1186/2046-0481-57 $-7-412$.

De Visscher, A., S. Piepers, F. Haesebrouck, and S. De Vliegher. 2016. Intramammary infection with coagulase-negative staphylococci at parturition: Species-specific prevalence, risk factors, and effect on udder health. J. Dairy Sci. 99:6457-6469. https://doi.org/10.3168/ jds.2015-10458.

Dohoo, I. R., and K. E. Leslie. 1991. Evaluation of changes in somatic cell counts as indicators of new intramammary infec- 
tions. Prev. Vet. Med. 10:225-237. https://doi.org/10.1016/0167 -5877(91)90006-N.

Dohoo, I. R., J. Smith, S. Andersen, D. F. Kelton, and S. Godden. 2011. Mastitis Research Workers Conference: Diagnosing intramammary infections: evaluation of definitions based on a single milk sample. J. Dairy Sci. 94:250-261. https://doi.org/10.3168/jds.2010 $-3559$.

du Preez, J. H., and A. S. Greeff. 1985. Comparison of the effect of antibiotic dry cow teat canal and intramammary dry cow therapy of dairy cows on the prevalence of teat canal and intramammary infections at calving. J. S. Afr. Vet. Assoc. 56:191-194.

Ekman, T., and O. Østerås. 2003 Mastitis control and dry cow therapy in the Nordic countries. 42nd Annu. Mtg. National Mastitis Council, Fort Worth, TX. National Mastitis Council, Madison, WI.

Godden, S., P. Rapnicki, S. Stewart, J. Fetrow, A. Johnson, R. Bey, and R. Farnsworth. 2003. Effectiveness of an internal teat seal in the prevention of new intramammary infections during the dry and early-lactation periods in dairy cows when used with a dry cow intramammary antibiotic. J. Dairy Sci. 86:3899-3911. https://doi .org/10.3168/jds.S0022-0302(03)73998-8.

Godden, S. M., E. Royster, J. Timmerman, P. Rapnicki, and H. Green. 2017. Evaluation of an automated milk leukocyte differential test and the California Mastitis Test for detecting intramammary infection in early- and late-lactation quarters and cows. J. Dairy Sci. 100:6527-6544. https://doi.org/10.3168/jds.2017-12548.

Green, M., J. Huxley, A. Madouasse, W. Browne, G. Medley, A. Bradley, A. Biggs, J. Breen, M. Burnell, A. Hayton, J. Husband, J. Reader, J. Statham, and M. Thorne. 2008. Making good decisions on dry cow management to improve udder health-Synthesising evidence in a Bayesian framework. Cattle Pract. 16:200-208.

Green, M. J., A. J. Bradley, G. F. Medley, and W. J. Browne. 2007. Cow, farm, and management factors during the dry period that determine the rate of clinical mastitis after calving. J. Dairy Sci. 90:3764-3776. https://doi.org/10.3168/jds.2007-0107.

Green, M. J., L. E. Green, G. F. Medley, Y. H. Schukken, and A. J. Bradley. 2002. Influence of dry period bacterial intramammary infection on clinical mastitis in dairy cows. J. Dairy Sci. 85:25892599. https://doi.org/10.3168/jds.S0022-0302(02)74343-9.

Halasa, T., M. Nielen, A. C. Whist, and O. Østerås. 2009b. Metaanalysis of dry cow management for dairy cattle. Part 2. Cure of existing intramammary infections. J. Dairy Sci. 92:3150-3157. https://doi.org/10.3168/jds.2008-1741.

Halasa, T., O. Østerås, H. Hogeveen, T. van Werven, and M. Nielen, 2009a. Meta-analysis of dry cow management for dairy cattle. Part 1. Protection against new intramammary infections. J. Dairy Sci. 92:3134-3149. https://doi.org/10.3168/jds.2008-1740.

Hayton, A. J. 2003. An investigation into the efficacy of an external teat sealant and of factors affecting new intramammary infection rate during the dry period on organic farms. Royal College of Veterinary Surgeons (RCVS) Thesis: Diploma in Cattle Health and Production. RCVS, London, UK.

Hockett, M., M. Payne, and R. Rodriguez. 2014. Milk leucocyte differential diagnosis as a tool to guide quarter-level, selective dry cow therapy. Regional Meeting of National Mastitis Council, Ghent, Belgium. National Mastitis Council, Madison, WI.

Huijps, K., and H. Hogeveen. 2007. Stochastic modeling to determine the economic effects of blanket, selective, and no dry cow therapy J. Dairy Sci. 90:1225-1234. https://doi.org/10.3168/jds.S0022 -0302(07)71611-9.

Johnson, A. P., S. M. Godden, E. Royster, S. Zuidhof, B. Miller, and J. Sorg. 2016. Randomized noninferiority study evaluating the efficacy of 2 commercial dry cow mastitis formulations. J. Dairy Sci. 99:593-607. https://doi.org/10.3168/jds.2015-10190.

Krömker, V., N. T. Grabowski, and J. Friedrich. 2014. New infection rate of bovine mammary glands after application of an internal teat seal at dry-off. J. Dairy Res. 81:54-58. https://doi.org/10 $.1017 /$ S0022029913000599.

McDougall, S., K. I. Parker, A. M. Weir, and C. W. Compton. 2008. Effect of application of an external teat sealant and/or oral treatment with a monensin capsule pre-calving on the prevalence and incidence of subclinical and clinical mastitis in dairy heifers. N. Z Vet. J. 56:120-129. https://doi.org/10.1080/00480169.2008.36820.

Milnes, A., and P. Platter. 2003. Gangrenous mastitis in a dairy herd. Vet. Rec. 153:635.

National Mastitis Council. 2017. Laboratory Handbook on Bovine Mastitis. 2017 ed. No. 3. National Mastitis Council Inc., Madison, WI

Neave, F. K., F. H. Dodd, and R. G. Kingwill. 1966. A method of controlling udder disease. Vet. Rec. 78:521-523.

Oliver, S. P., and B. M. Jayarao. 1997. Coagulase-negative staphylococcal intramammary infections in cows and heifers during the nonlactating and periparturient periods. Zentralbl. Veterinarmed. B 44:355-363.

Østerås, O., and L. Sandvik. 1996. Effects of selective dry-cow therapy on culling rate, clinical mastitis, milk yield and cow somatic cell count. A randomized clinical field study in cows. Zentralbl. Veterinarmed. B $43: 555-575$.

Pantoja, J. C., C. Hulland, and P. L. Ruegg. 2009. Dynamics of somatic cell counts and intramammary infections across the dry period Prev. Vet. Med. 90:43-54. https://doi.org/10.1016/j.prevetmed .2009.03.012.

Patel, K., S. M. Godden, E. E. Royster, J. A. Timmerman, B. A Crooker, and N. McDonald. 2017. Pilot Study: Impact of using a culture-guided selective dry cow therapy program targeting quarter-level treatment on udder health and antibiotic use. Bovine Pract. 51:48-57.

Piepers, S., Y. H. Schukken, P. Passchyn, and S. De Vliegher. 2013. The effect of intramammary infection with coagulase-negative staphylococci in early lactating heifers on milk yield throughout first lactation revisited. J. Dairy Sci. 96:5095-5105. https://doi .org/10.3168/jds.2013-6644.

Poutrel, B., and P. Rainard. 1981. California Mastitis Test guide of selective dry cow therapy. J. Dairy Sci. 64:241-248. https://doi .org/10.3168/jds.S0022-0302(81)82560-X.

Rabiee, A. R., and I. J. Lean. 2013. The effect of internal teat sealant products (Teatseal and Orbeseal) on intramammary infection, clinical mastitis, and somatic cell counts in lactating dairy cows: A meta-analysis. J. Dairy Sci. 96:6915-6931. https://doi.org/10 $.3168 /$ jds.2013-6544.

Rajala-Schultz, P. J., A. H. Torres, and F. J. Degraves. 2011. Milk yield and somatic cell count during the following lactation after selective treatment of cows at dry-off. J. Dairy Res. 78:489-499. https://doi.org/10.1017/S0022029911000690.

Reyher, K. K., D. Haine, I. R. Dohoo, and C. W. Revie. 2012. Examining the effect of intramammary infections with minor mastitis pathogens on the acquisition of new intramammary infections with major mastitis pathogens-A systematic review and metaanalysis. J. Dairy Sci. 95:6483-6502. https://doi.org/10.3168/jds $.2012-5594$.

Robert, A., N. Bareille, P. Roussel, B. Poutrel, V. Heuchel, and H. Seegers. 2006a. Interdependence of udder quarters for new intramammary infection during the dry period in cows submitted to selective antibiotic therapy. J. Dairy Res. 73:345-352. https://doi .org/10.1017/S0022029906001981.

Robert, A., H. Seegers, and N. Bareille. 2006b. Incidence of intramammary infections during the dry period without or with antibiotic treatment in dairy cows - A quantitative analysis of published data. Vet. Res. 37:25-48. https://doi.org/10.1051/vetres:2005047.

Schepers, A. J., T. J. Lam, Y. H. Schukken, J. B. Wilmink, and W. J. Hanekamp. 1997. Estimation of variance components for somatic cell counts to determine thresholds for uninfected quarters. J. Dairy Sci. 80:1833-1840. https://doi.org/10.3168/jds.S0022 -0302(97)76118-6.

Scherpenzeel, C. G., I. E. den Uijl, G. van Schaik, R. G. Olde Riekerink, J. M. Keurentjes, and T. J. Lam. 2014. Evaluation of the use of dry cow antibiotics in low somatic cell count cows. J. Dairy Sci. 97:3606-3614. https://doi.org/10.3168/jds.2013-7655.

Scherpenzeel, C. G., I. E. den Uijl, G. van Schaik, R. G. Riekerink, H. Hogeveen, and T. J. Lam. 2016. Effect of different scenarios for selective dry-cow therapy on udder health, antimicrobial us- 
age, and economics. J. Dairy Sci. 99:3753-3764. https://doi.org/ 10.3168/jds.2015-9963.

Schukken, Y. H., R. N. Gonzalez, L. L. Tikofsky, H. F. Schulte, C. G. Santisteban, F. L. Welcome, G. J. Bennett, M. J. Zurakowski, and R. N. Zadoks. 2009. CNS mastitis: Nothing to worry about? Vet. Microbiol. 134:9-14. https://doi.org/10.1016/j.vetmic.2008 .09.014.

Schukken, Y. H., J. Vanvliet, D. Vandegeer, and F. J. Grommers. 1993. A randomized blind trial on dry cow antibiotic infusion in a low somatic cell count herd. J. Dairy Sci. 76:2925-2930. https:// doi.org/10.3168/jds.S0022-0302(93)77632-8.

Schukken, Y. H., D. J. Wilson, F. Welcome, L. Garrison-Tikofsky, and R. N. Gonzalez. 2003. Monitoring udder health and milk quality using somatic cell counts. Vet. Res. 34:579-596. https://doi.org/10 .1051 vetres:2003028.

Smith, A., F. K. Neave, and F. H. Dodd. 1966. Methods of reducing the incidence of udder infection in dry cows. Vet. Rec. 79:233-236.

Timms, L. L. 2004. Field trial evaluations of a novel persistent barrier teat dip for preventing mastitis during the dry period and as a potential substitute for dry cow antibiotic therapy. Animal Industry Report: AS 650, ASL R1914. Iowa State University, Ames.

Todhunter, D. A., K. L. Smith, J. S. Hogan, and P. S. Schoenberger. 1991. Gram-negative bacterial infections of the mammary gland in cows. Am. J. Vet. Res. 52:184-188.
Torres, A. H., P. J. Rajala-Schultz, F. J. Degraves, and K. H. Hoblet. 2008. Using dairy herd improvement records and clinical mastitis history to identify subclinical mastitis infections at dry-off. J. Dairy Res. 75:240-247. https://doi.org/10.1017/S0022029908003257.

USDA-APHIS (Animal and Plant Health Inspection Service). 2016a. Dairy 2014: Milk quality, milking procedures, and mastitis in the United States, 2014. Report 704.0916. USDA-APHIS-Veterinary Services-Center for Epidemiology and Animal Health-National Animal Health Monitoring System (NAHMS), Fort Collins, CO.

USDA-APHIS (Animal and Plant Health Inspection Service). 2016b. Dairy 2014: Dairy cattle management practices in the United States, 2014. Report 704.0916. USDA-APHIS-Veterinary Services-Center for Epidemiology and Animal Health-National Animal Health Monitoring System (NAHMS), Fort Collins, CO.

Vanderhaeghen, W., S. Piepers, F. Leroy, E. Van Coillie, F. Haesebrouck, and S. De Vliegher. 2015. Identification, typing, ecology and epidemiology of coagulase negative staphylococci associated with ruminants. Vet. J. 203:44-51. https://doi.org/10.1016/j.tvjl .2014.11.001. 